\title{
Bio-optical characterization of selected cyanobacteria strains present in marine and freshwater ecosystems
}

\author{
Bożena Wojtasiewicz $^{1,2} \cdot$ Joanna Stoń-Egiert ${ }^{3}$
}

Received: 12 July 2015 / Revised and accepted: 21 October 2015 / Published online: 14 January 2016

(C) The Author(s) 2016. This article is published with open access at Springerlink.com

\begin{abstract}
The optical properties, i.e., absorption and scattering spectra of ten strains of cyanobacteria from the Baltic Sea and Pomeranian lakes (Aphanizomenon flos-aquae KAC 15, Microcystis aeruginosa CCNP 1101, Anabaena sp. CCNP 1406, Synechocystis salina CCNP 1104, Phormidium sp. CCNP 1317, Nodularia spumigena CCNP 1401, Synechococcus sp. CCNP 1108, Nostoc sp. CCNP 1411, Cyanobacterium sp. CCNP 1105, Pseudanabaena cf. galeata CCNP 1312) grown under low light conditions were investigated. Moreover, the chlorophylls, carotenoids, and phycobilin composition as well as the size structure of chosen cyanobacteria were measured. Studied species revealed high diversity both in optical properties with the absorption spectra similarity index ranging from 0.67 to 0.94 and the pigment composition. The chlorophyll-specific absorption coefficient at $440 \mathrm{~nm} a_{p h}{ }^{*}(440)$ varied between 0.017 and $0.065 \mathrm{~m}^{2} \mathrm{mg}^{-1}$. The influence of the package effect was only observed in the case of large filamentous cyanobacteria like $N$. spumigena or Nostoc sp. Interestingly, the package effect factor $Q_{a}{ }^{*}(675)$ for large-celled Anabaena sp. was 0.92 . Besides chlorophyll $a$, only echinenone, $\beta$-carotene, and phycocyanin were present in all analyzed cyanobacteria strains. Zeaxanthin, which is widely used as a marker pigment for
\end{abstract}

Bożena Wojtasiewicz

bozena.wojtasiewicz@ug.edu.pl

Joanna Stoń-Egiert

aston@iopan.gda.pl

1 Department of Physical Oceanography, Institute of Oceanography, University of Gdańsk, Marszałka Piłsudskiego 46, 81-378 Gdynia, Poland

2 CSIRO Oceans and Atmosphere, Floreat, WA, Australia

3 Marine Physics Department Polish Academy of Sciences, Powstańców Warszawy 55, 81-712 Sopot, Poland cyanobacteria, was absent in the toxic $N$. spumigena and Anabaena sp., which are the species that occur in the Baltic Sea most frequently causing summer cyanobacterial blooms. The investigation also showed that the sample preservation technique can introduce some major errors within the absorption band affected by the phycocyanin absorption.

Keywords Cyanobacteria $\cdot$ Chlorophyll $\cdot$ Carotenoids Phycobilins $\cdot$ Absorption $\cdot$ Size structure

\section{Introduction}

The energy from the sun reaching the Earth's surface is the main source of energy which is absorbed by sea water. It has been estimated that even more than $90 \%$ of the solar energy at the sea surface is absorbed and transformed into different kinds of internal energy necessary for various types of processes (e.g., Woźniak and Dera 2007). Among them, the photosynthesis and water heating seem to be the most important from the point of view of their consequences in the whole ecosystems. The knowledge on the absorptive properties of seawater, especially within the visible band, seems to be crucial for many studies on marine environment, like modeling the solar energy transport within the water column (Mobley et al. 1993; Mobley 1994; Chami et al. 2001), modeling the productivity of water reservoirs (e.g., Sosik 1996), or in various kinds of remote sensing algorithms (Stramska et al. 2003; Woźniak 2014).

The optically active seawater constituents are water molecules, colored dissolved organic matter (CDOM), and particulates, including living phytoplankton. In the Baltic Sea, the main bloom-forming organisms in summer are cyanobacteria also called blue-green algae. They are prokaryotic organisms capable to photosynthesize and characterized by both bacterial and plant features. Cyanobacteria can exist as filaments, single 
cells, and colonies. Some of the species are capable of atmospheric nitrogen fixation. The antennae system of the photosynthetic apparatus in all cyanobacteria, besides carotenoids, is formed by complexes of various biliproteins called phycobilisomes located in the membranes of the thylakoids (e.g., MacColl 1998). The most commonly occurring phycobilins that absorb light within the band from 450 to $660 \mathrm{~nm}$ are phycoerythrin (PE), phycocyanin (PC), and allophycocyanin (AP) (e.g., Grossman et al. 1993). The presence of various types of pigments whose concentration is highly variable and dependent on the environmental conditions is the main factor influencing the spectra of visible light absorption by phytoplankton communities.

Over the past decades, an increase in the productivity and occurrence of potentially toxic cyanobacterial blooms has been observed in coastal and open waters of the Baltic Sea and some Polish Pomeranian lakes (e.g., Pliński et al. 1998). Massive cyanobacteria blooms occur almost every summer covering the area reaching up to $100,000 \mathrm{~km}^{2}$ (e.g., Kahru et al. 1994). Nodularia spumigena, Aphanizomenon flos-aque as well as some species of the genus Anabaena are the dominant cyanobacteria occurring in the Gulf of Gdańsk (Pliński et al. 2007), whereas Microcystis spp. are by far the most commonly occurring cyanobacteria in freshwater reservoirs (Kobos et al. 2005, 2013). Picocyanobacteria like Synechococcus spp. or Synechocystis spp. also play a significant role during blooms (Mazur-Marzec et al. 2013). Their biomass can pose up to $80 \%$ of total bloom biomass, and they can be responsible for even $50 \%$ of primary production in the bloom (e.g., Stal et al. 2003). Besides these dominating species, other species like Pseudanabaena spp. are also present in the Baltic Sea and freshwater reservoirs of cyanobacterial communities (Stal et al. 2003; Mazur-Marzec et al. 2013). Considering the production of biologically active compounds, both toxins and potential pharmaceuticals, the Baltic cyanobacteria have been intensively studied recently.
Among the species considered in this study, cyanobacteria strain N. spumigena CCNP1401 produces the most active compounds, including proteases and phosphatase inhibitors (Mazur-Marzec et al. 2015). The extracts from the strains studied here usually cause protein phosphatase 1 inhibition (Microcystis aeruginosa CCNP 1101, Anabaena sp. CCNP 1406, Synechocystis salina CCNP 1104, N. spumigena CCNP 1401, Nostoc sp. CCNP 1411). Some of the strains produce protein phosphatase $2 \mathrm{~A}$, trypsin, thrombin, and carboxypeptidase-A inhibitors. The cyanobacterial compounds also have a strong impact on the growth of bacteria and fungi (Mazur-Marzec et al. 2015). It has been suggested that some of the Baltic alleged to be non-toxic. Aphanizomenon flos-aquae strains can produce bioactive compounds that can influence plankton composition and activity (Sellner 1997). A summary of bioactivity of studied cyanobacteria is given in Table 1.

Considering the high importance of the light absorption by phytoplankton from the point of view of productivity of water reservoirs, it is necessary to know the phytoplankton optical properties. The absorption coefficient of phytoplankton is somewhat difficult to determine, and therefore, many different techniques have been developed. The most common one is to collect phytoplankton cells on a glass fiber filter and determine the optical density of the collected material with the use of a spectrophotometer equipped with an integrating sphere (Tassan and Ferrari 1995; Röttgers and Gehnke 2012) and then to remove the pigments by extracting (Kishino et al. 1985) or oxidizing them (Tassan and Ferrari 1995). The phytoplankton absorption is obtained by subtracting the absorption by the bleached material from the absorption by total particulate matter. Another approach is to reconstruct the spectra using the information on the concentration of five main pigment groups, i.e., chlorophyll $a, b$, and $c$ and photosynthetic and photoprotective carotenoids (Bidigare et al. 1990; Hoepffner and Sathyendranath 1991; Ficek et al. 2004).

Table 1 Metabolites detected $(+)$ in the studied strains of cyanobacteria and the inhibition of enzymes by cyanobacterial extracts (for details, see Mazur-Marzec et al. 2015)

\begin{tabular}{|c|c|c|c|c|c|c|c|c|c|}
\hline Strain & Species & $\mathrm{MC}$ & NOD & AP & AER & SPU & CPL & $\mathrm{NCP}$ & Inhibition \\
\hline KAC 15 & A. flos-aquae & \multicolumn{8}{|c|}{ Not analyzed } \\
\hline CCNP 1101 & M. aeruginosa & + & & & + & & & & + \\
\hline CCNP 1406 & Anabaena sp. & & & & & & & & + \\
\hline CCNP 1104 & S. salina & & & & & & & & + \\
\hline CCNP 1317 & Phormidium sp. & & & & & & & & \\
\hline CCNP 1401 & N. spumigena & & + & + & + & + & & & + \\
\hline CCNP 1108 & Synechococcus sp. & & & & & & & & + \\
\hline CCNP 1411 & Nostoc sp. & & & & & & + & + & + \\
\hline CCNP 1105 & Cyanobacterium sp. & & & & & & & & \\
\hline CCNP 1312 & P. cf. galeata & & & & & & & & \\
\hline
\end{tabular}

$M C$ microcystin, $N O D$ nodularin, $A P$ anabaenopeptin, $A E R$ aeruginosin, $S P U$ spumigin, $C P L$ cyanopeptolin, $N C P$ nostocyclopeptide 
However, this approach does not account for the group of phycobilin pigments that are always present in cyanobacteria cells. Moreover, these water-soluble pigments are also present in different algal groups like red algae, cryptomonads, prochlorophytes, or glaucocytophytes (Roy et al. 2011). Considering the fact that the magnitude and the spectral shape of the absorption coefficient of phytoplankton result mostly from their photosynthetic and photoprotective pigment composition which is somewhat unique for certain phytoplankton groups which contain characteristic markers and accessory pigments (Mackey et al. 1996). Therefore, in recent years, a number of studies applying the statistical analysis of in vivo phytoplankton absorption spectra in taxonomical identification of water samples have been performed (Moberg et al. 2002; Lokuhewage et al. 2005; Lokuhewage and Fujino 2011). Their results showed that using the absorptive properties together with appropriate statistical approach can be a valuable tool in detecting phytoplankton groups and even species.

The aim of this study was to study and analyze the variability of the optical properties of cyanobacteria commonly occurring in Baltic Sea waters and to link these optical features with the pigment composition of studied cyanobacteria. Our study focused on the natural variability of these characteristics among phytoplankton from one taxonomical group grown under the same light and nutrient conditions. Our aim here was not to find the bio-optical method for distinguishing between selected cyanobacteria species and toxic and non-toxic species. The knowledge of such differences can be very useful in taxonomical identification of species and can be applied in creating algorithms for remote sensing techniques in monitoring of aquatic environment.

\section{Methods}

\section{Culturing procedures}

Ten strains of cyanobacteria (A. flos-aquae KAC 15, M. aeruginosa CCNP 1101, Anabaena sp. CCNP 1406, S. salina CCNP 1104, Phormidium sp. CCNP 1317, N. spumigena CCNP 1401, Synechococcus sp. CCNP 1108, Nostoc sp. CCNP 1411, Cyanobacterium sp. CCNP 1105, Pseudanabaena cf. galeata CCNP 1312) were analyzed. All analyzed strains, besides A. flos-aquae, came from the Culture Collection of Northern Poland of the Laboratory of Biochemical Ecology of Microorganisms from the University of Gdansk. The monoculture of A. flos-aquae KAC 15 was obtained from the University of Kalmar. All monocultures were grown under low light conditions $\left(7 \mu \mathrm{mol}\right.$ photons $\left.\mathrm{m}^{-2} \mathrm{~s}^{-1}\right)$ with the use of Sylvania Luxline Plus Cool White de Luxe at the temperature of $22 \pm 0.1{ }^{\circ} \mathrm{C}$. Such low light intensity is comparable to that observed at the depth of ca. $5 \mathrm{~m}$ in Baltic waters when concentrations of suspended matter is high, e.g., during summer blooms. All analyzed organisms were grown in batch cultures in Z8 medium (Kotai 1972). In the case of $N$. spumigena, the medium was enriched with $\mathrm{NaCl}$ to obtain the salinity of 7 PSU. Before the measurements, the cultures were diluted daily for several days with fresh medium in order to maintain the cells in the exponential phase of growth and to minimize concentrations of detrital material. Moreover, the cell densities were adjusted to keep the cultures optically thin, in order to minimize shading and multiple scattering during absorption measurements.

\section{Optical measurements and spectra analysis}

Suspension measurements Optical measurements of the spectral absorption, $a_{p}(\lambda)$, and beam attenuation coefficient, $c_{p}(\lambda)$, were performed within the spectral region from 350 to $800 \mathrm{~nm}$ at $1-\mathrm{nm}$ intervals with the use of Perkin Elmer Lambda 850 dual-beam spectrophotometer equipped with a 15-cm integrating sphere (Labsphere). The beam attenuation was measured with the cuvette placed about $20 \mathrm{~cm}$ from the integrating sphere entrance, and the geometry of measurement minimized the angle of acceptance for detecting light to less than $1^{\circ}$ (e.g., Stramski and Piskozub 2003). The absorption measurements were made on samples of particle suspension in a $1-\mathrm{cm}$ cuvette that was placed inside the integrating sphere (e.g., Stramski et al. 2002). Baseline spectra for both measurements were determined on the sample filtrate collected upon filtration through a prewashed $0.2-\mu \mathrm{m}$ polycarbonate membrane filter (Nuclepore) in order to eliminate the influence of CDOM on the obtained spectra. All optical measurements were made on samples with optical density $O D$ at $400 \mathrm{~nm}$ less than 0.3 in the beam attenuation setup to ensure the insignificant multiple scattering effects within the $1-\mathrm{cm}$ cuvette (van de Hulst 1957). For each sample, scans of the optical density were made on at least three aliquots of particle suspension and the final sample spectrum was obtained by averaging the replicate scans. The particle spectral absorption coefficient $a_{p}(\lambda)\left(\mathrm{m}^{-1}\right)$ and the beam attenuation coefficient $a_{p}(\lambda)\left(\mathrm{m}^{-1}\right)$ were calculated by multiplying the appropriate baseline-corrected optical density values of the sample by 2.3 and dividing by the optical path length $(0.01 \mathrm{~m})$. The scattering coefficient of particles $b_{p}(\lambda)$ $\left(\mathrm{m}^{-1}\right)$ was calculated as the difference between the beam attenuation coefficient and absorption coefficient. Specific absorption and scattering and beam attenuation coefficients were obtained by dividing the appropriate spectra by the chlorophyll $a$ concentrations measured using the highperformance liquid chromatography (HPLC) as described in the following section. 

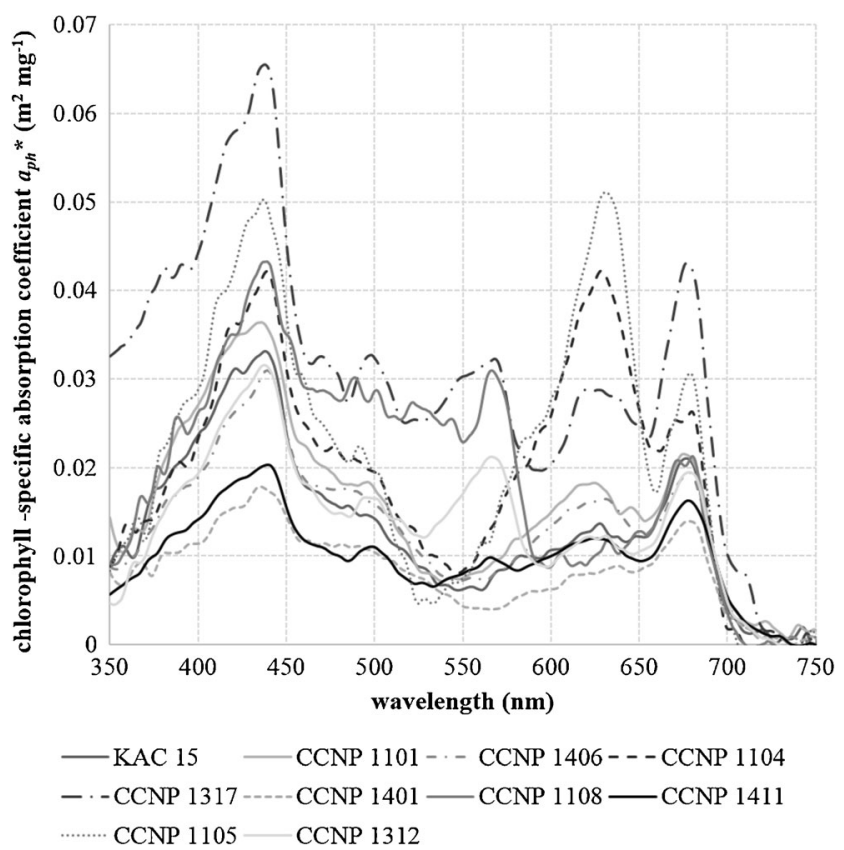

Fig. 1 Chlorophyll-specific absorption spectra of cyanobacteria strains: Aphanizomenon flos-aquae KAC 15, Microcystis aeruginosa CCNP 1101, Anabaena sp. CCNP 1406, Synechocystis salina CCNP 1104, Phormidium sp. CCNP 1317, Nodularia spumigena CCNP 1401, Synechococcus sp. CCNP 1108, Nostoc sp. CCNP 1411, Cyanobacterium sp. CCNP 1105, Pseudanabaena cf. galeata CCNP 1312

Even though the cultures were grown under favorable conditions without nutrient limitation, some influence of detrital matter on the magnitude and the spectral shape of total absorption $a_{p}(\lambda)$ $\left(\mathrm{m}^{-1}\right)$ was noted. The phytoplankton absorption was measured in the same way as the total particulate absorption after depigmentation of a sample by adding a solution of sodium hypochlorite as an oxidizing agent (e.g., Tassan and Ferrari 1995) against the sample filtrate after sample filtration through a prewashed $0.2-\mu \mathrm{m}$ polycarbonate membrane filter as a blank. No decrease in the absorption of the filtrate was noted during filtration as observed in some studies (Röttgers et al. 2007); therefore, it could be used as a reference. In such a way, after multiplying the obtained optical densities by 2.3 and dividing by the cuvette length, the absorption spectra of detrital matter $a_{\text {det }}(\lambda)\left(\mathrm{m}^{-1}\right)$ were obtained. The phytoplankton absorption coefficient $a_{p h}(\lambda)\left(\mathrm{m}^{-1}\right)$ was obtained by subtracting the detrital absorption from the total absorption coefficient $a_{p}(\lambda)\left(\mathrm{m}^{-1}\right)$. After calculating the magnitudes of all coefficients, the spectra were smoothed with the use of Savitzky-Golay smoother with 11-nm window with the use of OriginPro software.

Filter technique In the case of each cyanobacteria culture, the absorption spectra were measured also after collecting them onto a glass fiber filter. We measured both fresh and frozen cultures in order to check if this common method of sample preserving in liquid nitrogen or the absorption measurement procedure can affect the absorption spectra. The optical density in this case was measured after inserting the sample into the integrating sphere with use of a special commercially available clip style holder (e.g., Röttgers and Gehnke 2012). After the first measurement, the pigments were oxidized with the use of sodium hypochlorite, the oxidizing agent was washed out from the filter, and the optical density was measured again (e.g., Tassan and Ferrari 1995). The same procedure was performed for samples frozen in liquid nitrogen. This dataset was used to evaluate the measurement error connected to freezing and thawing samples during the measurement. The optical densities obtained for fresh $\left(O D_{\text {fresh }}\right)$ and frozen $\left(O D_{\text {frozen }}\right)$ samples were compared.

\section{Methodology of pigment analysis}

Due to different physicochemical properties of tested pigment compounds, the appropriate methodology was used for their isolation, identification, and precise quantification in examined algae strains.
Table 2 Basic absorptive properties of ten cyanobacteria strains at 440,630 , and $675 \mathrm{~nm}$

\begin{tabular}{llllll}
\hline Strain & Species & $\begin{array}{l}a_{p h}^{*}(440) \\
\left(\mathrm{m}^{2} \mathrm{mg}^{-1}\right)\end{array}$ & $\begin{array}{l}a_{p h}^{*}(630) \\
\left(\mathrm{m}^{2} \mathrm{mg}^{-1}\right)\end{array}$ & $\begin{array}{l}a_{p h}^{*}(675) \\
\left(\mathrm{m}^{2} \mathrm{mg}^{-1}\right)\end{array}$ & $\begin{array}{l}a_{p h}(440): a_{p h}(675) \\
-\end{array}$ \\
\hline KAC 15 & A. flos-aquae & 0.033 & 0.013 & 0.021 & 1.567 \\
CCNP 1101 & M. aeruginosa & 0.036 & 0.018 & 0.022 & 1.658 \\
CCNP 1406 & Anabaena sp. & 0.031 & 0.017 & 0.019 & 1.623 \\
CCNP 1104 & S. salina & 0.042 & 0.042 & 0.025 & 1.691 \\
CCNP 1317 & Phormidium sp. & 0.065 & 0.028 & 0.042 & 1.530 \\
CCNP 1401 & N. spumigena & 0.017 & 0.008 & 0.014 & 1.253 \\
CCNP 1108 & Synechococcus sp. & 0.043 & 0.011 & 0.020 & 2.135 \\
CCNP 1411 & Nostoc sp. & 0.020 & 0.012 & 0.016 & 1.271 \\
CCNP 1105 & Cyanobacterium sp. & 0.048 & 0.051 & 0.030 & 1.640 \\
CCNP 1312 & P. cf. galeata & 0.031 & 0.012 & 0.019 & 1.617 \\
\hline
\end{tabular}




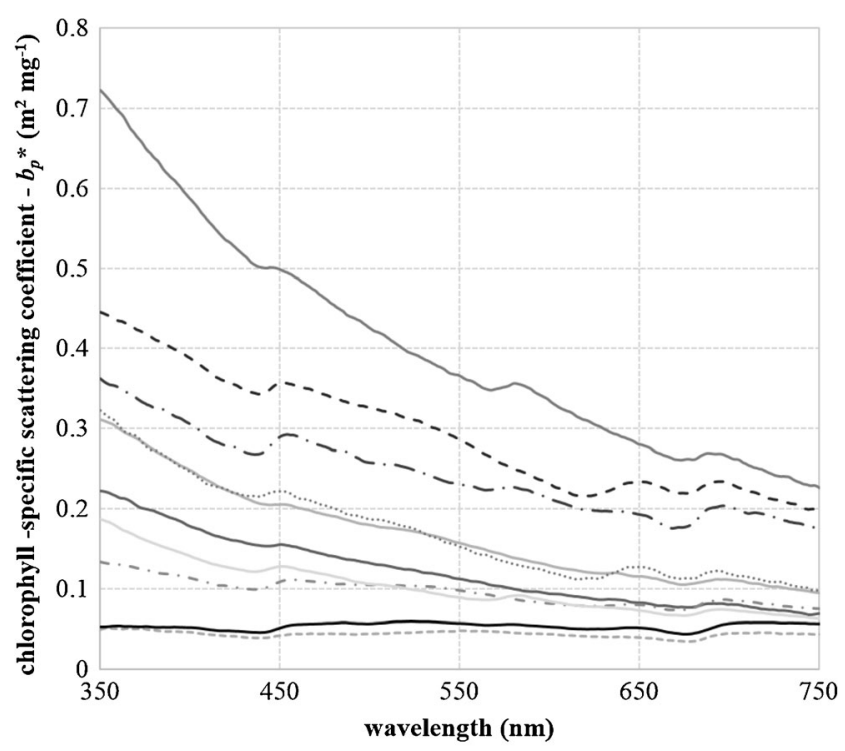

$-\mathrm{KAC} 15-\mathrm{CCNP} 1101-\cdot-\mathrm{CCNP} 1406---\mathrm{CCNP} 1104$

-- - CCNP $1317---\mathrm{CCNP} 1401-\mathrm{CCNP} 1108-\mathrm{CCNP} 1411$

....... CCNP $1105-$ CCNP 1312

Fig. 2 Chlorophyll-specific scattering spectra of cyanobacteria strains: Aphanizomenon flos-aquae KAC 15, Microcystis aeruginosa CCNP 1101, Anabaena sp. CCNP 1406, Synechocystis salina CCNP 1104, Phormidium sp. CCNP 1317, Nodularia spumigena CCNP 1401, Synechococcus sp. CCNP 1108, Nostoc sp. CCNP 1411, Cyanobacterium sp. CCNP 1105, Pseudanabaena cf. galeata CCNP 1312

Extraction of pigments from phytoplankton cells Two types of extraction media were used to isolate pigments from algal cells: $90 \%$ acetone solution with respect to chlorophylls and carotenoids (Parsons et al. 1984) and extraction medium consisted of $0.25 \mathrm{M}$ Trizma Base, hydrated $10 \mathrm{mM}$ disodium EDTA $\left(2 \mathrm{H}_{2} \mathrm{O}\right)$, and $2 \mathrm{mg} \mathrm{cm}^{-3}$ lysozyme; the initial $\mathrm{pH} 9$ was adjusted to final $5.5(\mathrm{HCl})$ - in case of extraction phycobiliproteins from cyanobacteria cells (according to Steward and Farmer 1984). Chlorophylls and carotenoids were extracted by mechanical grinding and sonication ( $2 \mathrm{~min}, 20 \mathrm{kHz}$, Cole Parmer, 4710 Series) in the darkness conditions at $4{ }^{\circ} \mathrm{C}$ for $2 \mathrm{~h}$. Procedure of isolation of phycobiliproteins from cells was based on combination of a gentle mechanical grinding and enzymatic (lysozyme) reaction in order to successfully disintegrate cell walls and improve pigment extraction efficiency in darkened room conditions. Filers were then incubated at $37^{\circ} \mathrm{C}$ for $2 \mathrm{~h}$ in a dry block heat bath (Thermoleader, Uniequip) and after that kept in dark at $4{ }^{\circ} \mathrm{C}$ for $24 \mathrm{~h}$. The extract was then centrifuged (20 min, $5{ }^{\circ} \mathrm{C}, 3210 \times \mathrm{g}$, Beckman, GS-6R) to remove the filters and cellular debris.

The clarified extracts were then subjected to the chromatographic analysis in case of chlorophylls and carotenoids and spectrofluorometric measurements in case of phycobilins.

Qualitative and quantitative designation of chlorophylls and carotenoids in cyanobacteria cells The chromatographic system HP1200 (Agilent, Perlan Technologies) used for chlorophyll and carotenoid isolation and separation was equipped with $\mathrm{C}_{18}$ LichroCARTLiChrospher100 RP18e (Merck) analytical column (dimension $250 \times 4 \mathrm{~mm}$, particle size $5 \mu \mathrm{m}$, and pore size $100 \AA$ ).

Pigments were isolated from extract by use of reverse-phase high-performance liquid chromatography (RP-HPLC), commonly used to analyze samples with wide polarity components, such pigments are. The method of pigment isolation and separation was introduced by Mantoura and co-workers (Mantoura and Llewellyn 1983), adopted and modified in later years by other researchers (Barlow et al. 1993; Stoń and Kosakowska 2002; Stoń-Egiert and Kosakowska 2005). Calibration of chromatographic system was based on commercially available chlorophylls and carotenoids (The International Agency for ${ }^{14} \mathrm{C}$ Determination DHI Institute for Water and Environment in Denmark).
Table 3 Selected light scattering and attenuation properties by ten cyanobacteria strains

\begin{tabular}{|c|c|c|c|c|c|}
\hline \multirow[t]{2}{*}{ Strain } & \multirow[t]{2}{*}{ Species } & \multirow[t]{2}{*}{$b_{p} *(600)\left(\mathrm{m}^{-1}\right)$} & \multicolumn{3}{|c|}{$a_{p}(\lambda) / c_{p}(\lambda)$} \\
\hline & & & Average & Min & Max \\
\hline KAC 15 & Aphanizomenon flos-aquae & 0.093 & 0.118 & 0.030 & 0.235 \\
\hline CCNP 1101 & Microcystis aeruginosa & 0.129 & 0.100 & 0.032 & 0.182 \\
\hline CCNP 1406 & Anabaena sp. & 0.082 & 0.132 & 0.015 & 0.262 \\
\hline CCNP 1104 & Synechocystis salina & 0.231 & 0.088 & 0.013 & 0.179 \\
\hline CCNP 1317 & Phormidium sp. & 0.212 & 0.115 & 0.008 & 0.218 \\
\hline CCNP 1401 & Nodularia spumigena & 0.044 & 0.187 & 0.019 & 0.363 \\
\hline CCNP 1108 & Synechococcus sp. & 0.333 & 0.067 & 0.017 & 0.107 \\
\hline CCNP 1411 & Nostoc sp. & 0.053 & 0.166 & 0.008 & 0.336 \\
\hline CCNP 1105 & Cyanobacterium sp. & 0.119 & 0.145 & 0.025 & 0.336 \\
\hline CCNP 1312 & Pseudanabaena cf. galeata & 0.083 & 0.131 & 0.008 & 0.238 \\
\hline
\end{tabular}




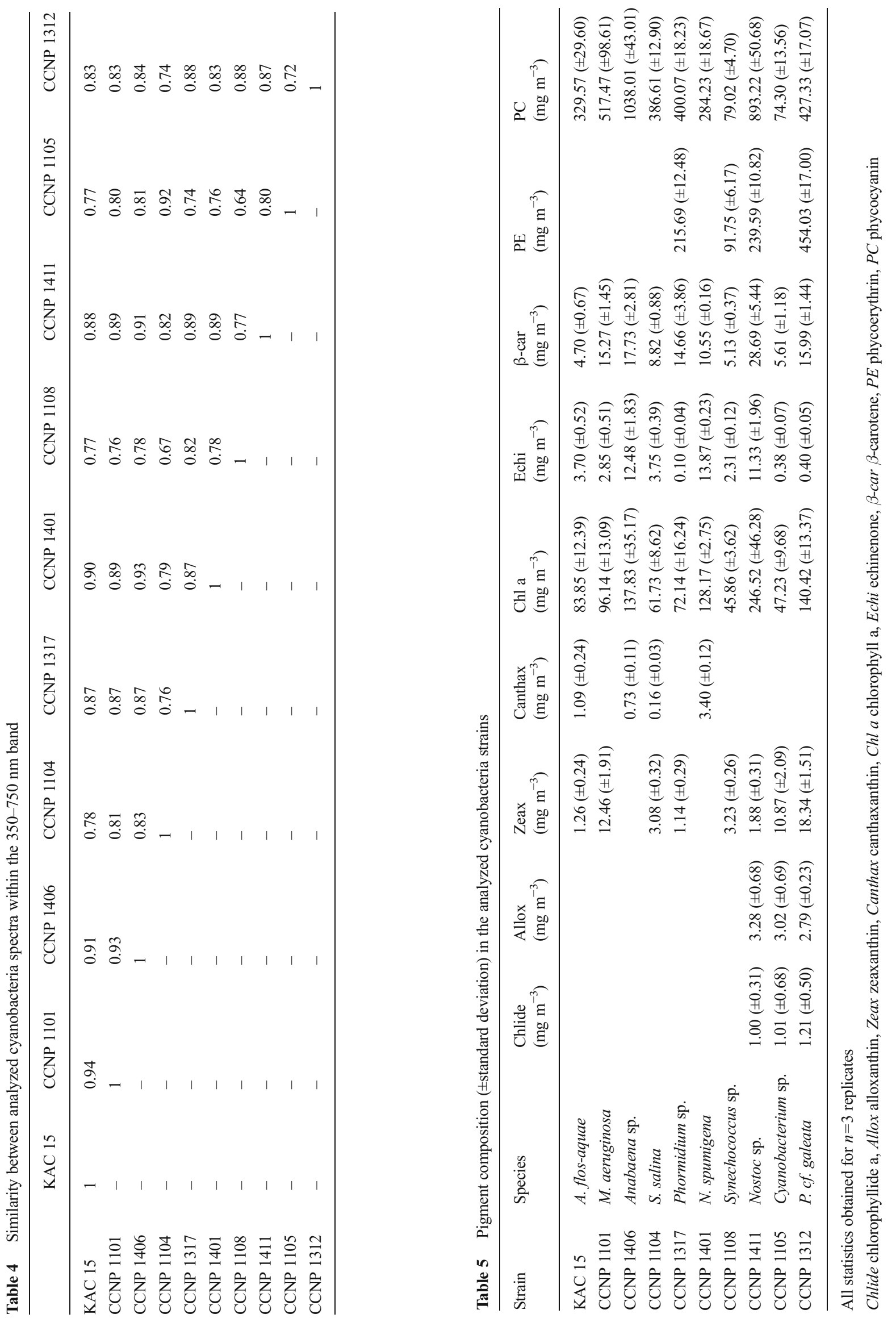


Qualitative and quantitative designation of phycobiliproteins in cyanobacteria cells Concentrations of phycocyanin and phycoerythrin were determined on the basis of spectrofluorometric measurements (Cary Eclipse, Varian, Agilent Technologies) of previously prepared extracts, which allows for obtaining spectra of fluorescence emission (500-700 nm) with resolution of $2 \mathrm{~nm}$ were obtained every $5 \mathrm{~nm}$ of excitation.

The calibration parameters and response factors for appropriate wavelengths of extinction and emission curves were performed for commercially available phycobilin standards (ProZyme Inc., USA) prepared in medium solution. The calibration analysis was carried out for three settings of excitation signal controlled by varying intense of xenon lamp, set at 600, 800, and $1000 \mathrm{~V}$. A detailed description of the methodology used is given in the work by Sobiechowska-Sasim et al. (2014).

\section{Size distribution determination}

Concentration of particles in known volume of analyzed samples, as well as the volumetric concentration of cyanobacteria cells, was obtained by the use of Multisizer 4 Coulter Counter (Beckman Coulter) equipped with a $100-\mu \mathrm{m}$ aperture (particle size range from 2 to $60 \mu \mathrm{m}$ ). The device uses the Coulter method, known as electrical sensing zone (ESZ), a method with high resolution and accuracy, additionally supported by digital pulse processor, which provides ultra-resolution, multi-channel analysis, and accuracy unattainable by other technologies and methods of measurement (volumetric pump precise is higher than $99.5 \%$ ). The application of $100 \mu \mathrm{m}$ aperture allows for precise designation of particles in 2-60 $\mu \mathrm{m}$ size range (treated as equivalent sphere diameter) divided into 400 size channels logarithmically spaced over the measured range. The aperture was calibrated by the use of internal standard, latex beads with modal size $19.66 \mu \mathrm{m}$ (Beckman Coulter), prepared in recommended concentration in double filtered through membrane filters (pore size
$0.2 \mu \mathrm{m}$ ) of artificial seawater (salinity 7 PSU). The measurements of particle size distribution (PSD) were made in three replicates for each sample using volumetric control mode of measurements (from 0.05 to $2 \mathrm{~cm}^{3}$ depending on particle content).

\section{Results}

\section{Optical properties of cyanobacteria strains}

The absorption features of the analyzed cyanobacteria strains differed both in the magnitude and the spectral shape of the absorption coefficient (Fig. 1, Table 2). On the average, the highest chlorophyll-specific absorption coefficient was observed in the case of Phormidium sp. CCNP $1317\left(0.065 \mathrm{~m}^{2} \mathrm{mg}^{-1}\right)$, whereas the lowest for $N$. spumigena CCNP 1401 $\left(0.017 \mathrm{~m}^{2} \mathrm{mg}^{-1}\right)$ and Nostoc sp. CCNP $1411\left(0.020 \mathrm{~m}^{2} \mathrm{mg}^{-1}\right)$.

The magnitude of $a_{p h} *(675)$ peak is mainly attributed to the chlorophyll $a$ and the package effect; however, in the case of cyanobacteria, it can be slightly affected by phycocyanin, whereas the $a_{p h}{ }^{*}(440)$ peak is influenced additionally by the accessory pigments. Therefore, the variations in its magnitude result from the pigment composition and content in a phytoplankton cell as well as from the package effect (e.g., Bricaud et al. 1995). The lowest values of $a_{p h}{ }^{*}(675)$ were observed for large-celled filamentous cyanobacterium N. spumigena (Table 1) which because of the size of the cells is mostly affected by the package effect. According to Bricaud et al. (1995), the dimensionless factor describing the package effect $Q_{a}{ }^{*}(675)$ was calculated. The lower the value of this factor, the higher is the influence of the package effect on the absorption coefficient spectra. For $N$. spumigena, the value of $Q_{a}{ }^{*}(675)$ was the lowest and equaled 0.67 . In other cases, the value of $Q_{a} *(675)$ was close to 1 which means that the package effect has low influence on the absorption properties of studied species. In the
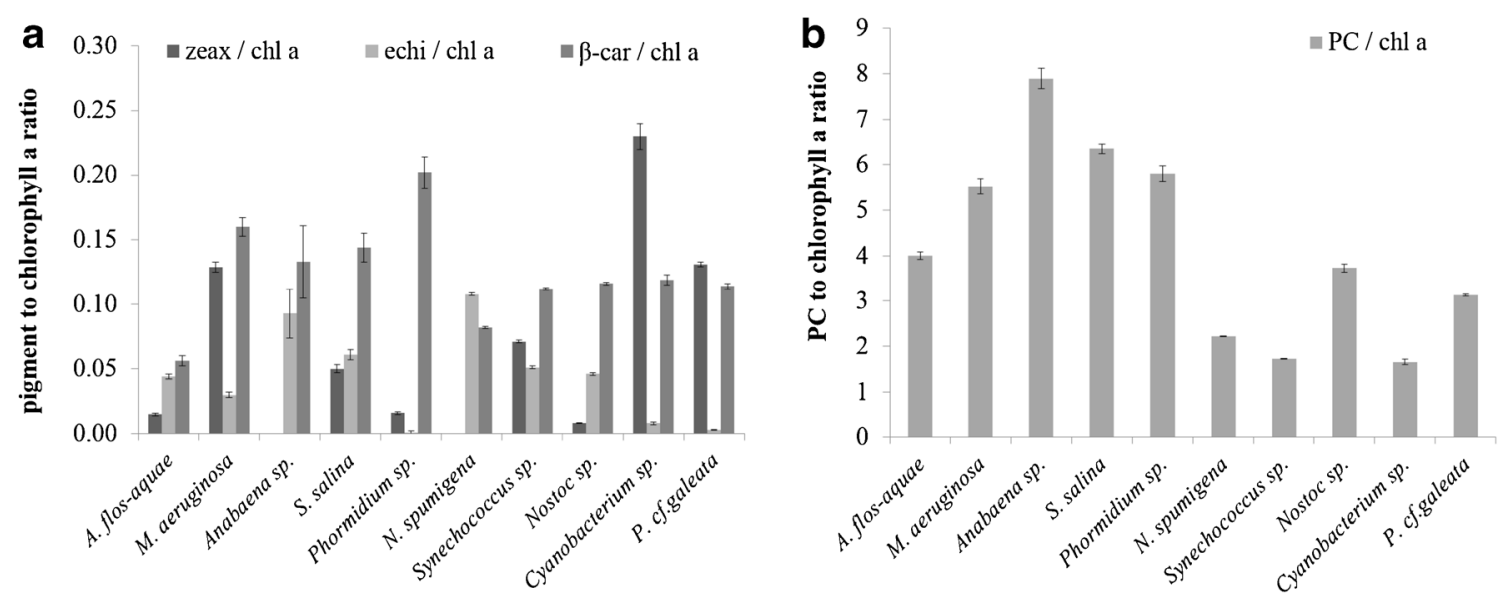

Fig. 3 Ratios of the zeaxanthin, echinenone, $\beta$-carotene, and phycocyanin concentration to chlorophyll $a$ concentration ( \pm standard deviation) in analyzed strains of cyanobacteria 


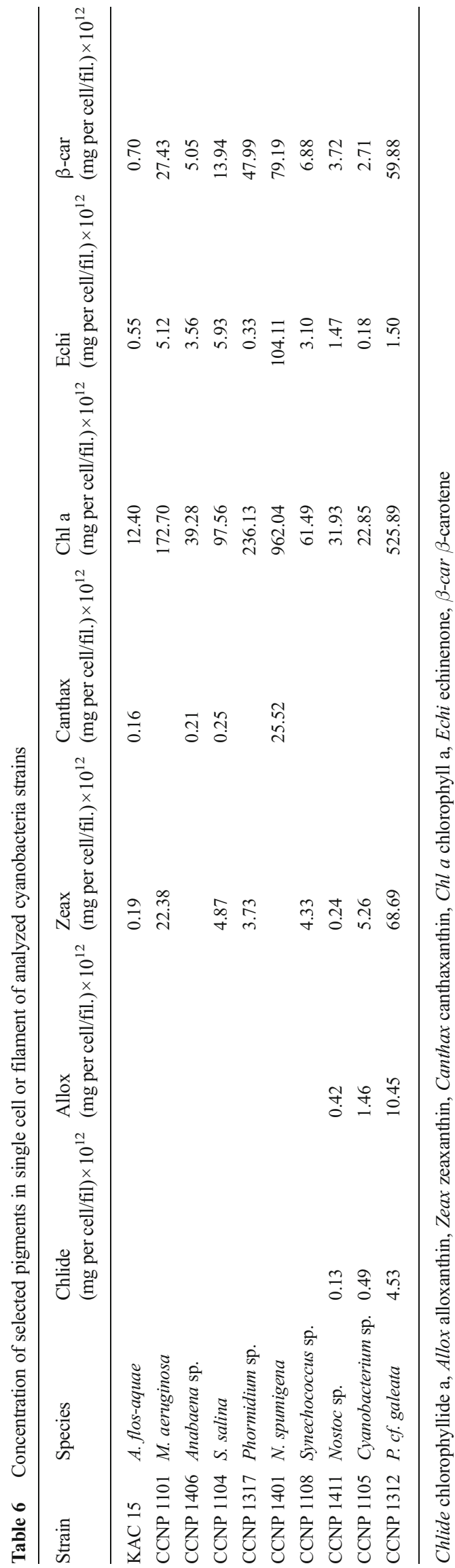

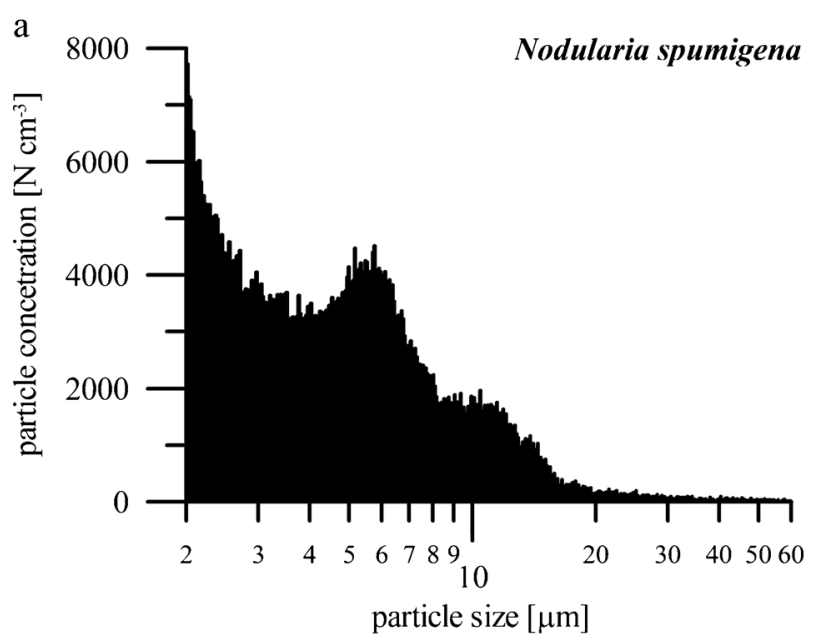
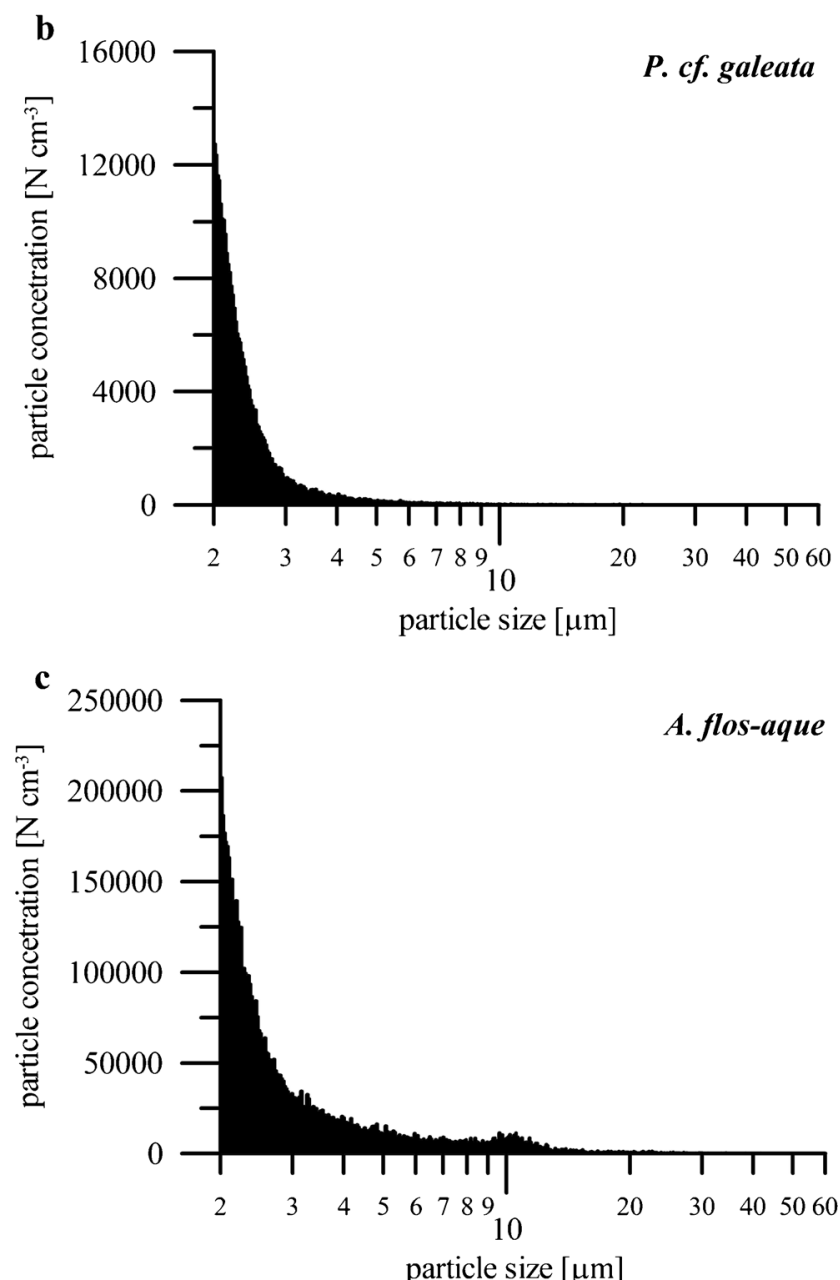

Fig. 4 Size distributions of cells/filaments of selected cyanobacteria: a Nodularia spumigena, b Pseudanabaena $c f$. galeata, and c Aphanizomenon flos-aquae

case of Phormidium sp., the value was 2.05 which is impossible because the limiting value of this coefficient is 1 . However, such values were also observed and could be caused by the absorption measurement technique inaccuracy or the influence of other pigments (Bricaud et al. 1995). The blue to red ratio 
Table 7 Relative differences in the optical densities for measurements of absorption using the filter technique for fresh and frozen samples

\begin{tabular}{lllll}
\hline \multirow{2}{*}{ Strain } & \multirow{2}{*}{ Species } & \multicolumn{3}{l}{ Relative difference } \\
\cline { 3 - 5 } & & $440 \mathrm{~nm}$ & $630 \mathrm{~nm}$ & $675 \mathrm{~nm}$ \\
\hline KAC 15 & Aphanizomenon flos-aquae & $7.5 \%$ & $33.8 \%$ & $8.8 \%$ \\
CCNP 1101 & Microcystis aeruginosa & $6.8 \%$ & $27.2 \%$ & $9.5 \%$ \\
CCNP 1406 & Anabaena sp. & $-2.0 \%$ & $10.6 \%$ & $-0.9 \%$ \\
CCNP 1104 & Synechocystis salina & $1.2 \%$ & $10.0 \%$ & $3.2 \%$ \\
CCNP 1317 & Phormidium sp. & $3.3 \%$ & $16.5 \%$ & $6.3 \%$ \\
CCNP 1401 & Nodularia spumigena & $16.6 \%$ & $19.8 \%$ & $15.5 \%$ \\
CCNP 1411 & Nostoc sp. & $5.1 \%$ & $21.9 \%$ & $11.7 \%$ \\
CCNP 1312 & Pseudanabaena cf. galeata & $25.6 \%$ & $37.9 \%$ & $26.2 \%$ \\
\hline
\end{tabular}

$a_{p h}(440): a_{p h}(675)$ that can be treated as the factor describing the relative (to chlorophyll $a$ ) contribution of accessory pigments to total absorption ranged between 1.25 (N. spumigena) to 2.14 (Synechococcus sp.) (Table 2).

Some of the analyzed strains were characterized by considerably high absorption coefficient values at $630 \mathrm{~nm}$, especially Cyanobacterium sp. CCNP 1105 and S. salina CCNP 1104 whose absorption coefficient values were as high as 0.051 and $0.042 \mathrm{~m}^{2} \mathrm{mg}^{-1}$, respectively (Table 1 ). In the case of

Cyanobacterium sp., the 630-nm peak was higher than both chlorophyll $a$ absorption peaks (Fig. 1, Table 2).

The analyzed cyanobacteria differed in the ability to scatter the light as well (Fig. 2). The highest and the most steep scattering coefficient spectrum was observed for the smallest, single-celled species Synechococcus sp. and S. salina (Fig. 2, Table 3). In the case of both these species, the average contribution of the absorption into total light attenuation was lower than $9 \%$. The most flat spectra with almost no light wavelength dependency were noted for $N$. spumigena and Nostoc sp. (Fig. 2). These organisms were also characterized by the largest sizes of their filaments (see Fig. 6).

In order to compare the magnitude and spectral shape of the absorption coefficient of analyzed cyanobacteria strains, we used the similarity index (SI) defined as follows (Millie et al. 2002):

$\mathrm{SI}=1-\frac{2}{\pi} \operatorname{arcos} \frac{\sum a_{i} b_{i}}{\sqrt{\sum a_{i}^{2} \sum b_{i}^{2}}}$

where $a_{i}$ and $b_{i}$ are the absorption coefficients at $\lambda_{i}$.

Despite the fact that all analyzed strains were cyanobacteria, a considerable variability in the spectral shape and magnitude of absorption coefficient was noted (Fig. 1, Table 4).

The most similar absorption spectra were observed in the case of $A$. flos-aquae and $M$. aeruginosa $(\mathrm{SI}=0.94)$, whereas the most

b
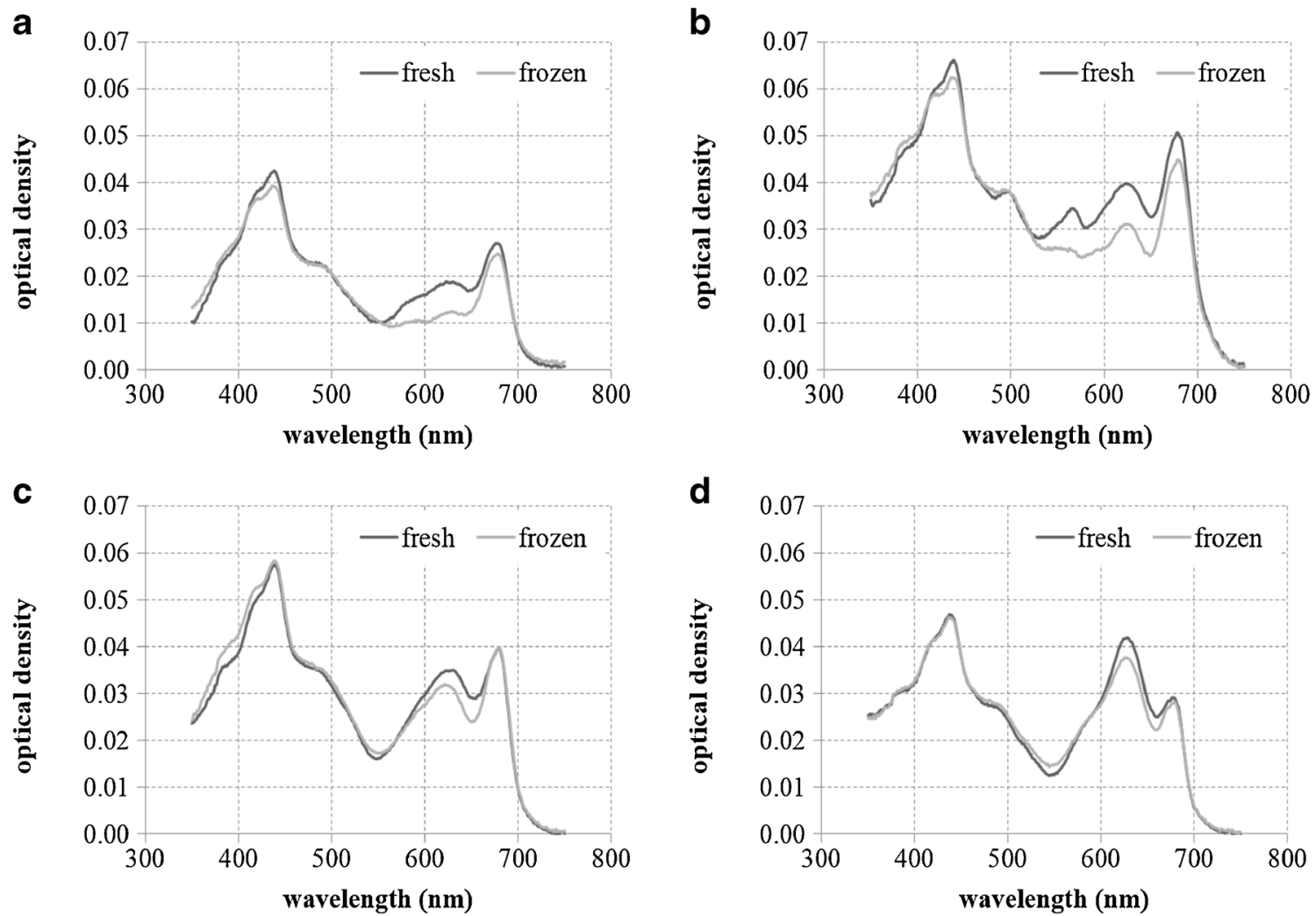

Fig. 5 Comparison of the optical density spectra measured using the filter technique for fresh and frozen cyanobacteria monoculture samples: a $A$. flosaquae, b M. aeruginosa, c Anabaena sp., and d Nostoc sp. 
different spectra were noted for S. salina and Synechococcus sp. $(\mathrm{SI}=0.67)$. Overall, the most different among all analyzed strains were the spectra of absorption by Phormidium sp. and $P$. $c f$. galeata, which can be also clearly seen in Fig. 1.

\section{Pigment composition in cyanobacteria}

The concentration of chlorophyll $a$, carotenoids, and phycobilins was measured separately for every analyzed strain. On the average, $88.55 \%$ of detected pigments were identified. Chlorophyll $a$ concentration varied from 47.2 (Cyanobacterium sp.) to $246.5 \mathrm{mg} \mathrm{m}^{-3}$ (Nostoc sp.). Lower values of concentration of this pigment were usually observed for small-celled strains. Besides chlorophyll $a$, only echinenone, $\beta$-carotene, and phycocyanin were present in all analyzed strains (Table 5). The concentration of phycocyanin was much higher than concentrations of other pigments, e.g., for Anabaena sp., it was almost eight times higher than the chlorophyll $a$ concentration. Zeaxanthin, which is widely used as a marker pigment for cyanobacteria (e.g., Schagerl and Müller 2006), was observed in eight out of ten analyzed strains with the maximum concentration of $18.3 \mathrm{mg} \mathrm{m}^{-3} \mathrm{ob}-$ served in the case of $P$. cf. galeata. It was absent in $N$. spumigena and Anabaena sp., which are the species that occur in the Baltic Sea most frequently. Small amounts of zeaxanthin were also observed in previous studies on pigment production in blue-green algae (Goodwin 1957). Together with large ranges of pigment concentrations observed for various strains (Fig. 3), it could be observed that also the ratio of accessory pigments to chlorophyll $a$ was not constant, especially in the case of $\beta$-carotene and echinenone. This can indicate different mechanisms of photoacclimation in the analyzed strains.

Considering the number of particles (single cells or filaments) in analyzed samples within the $2-60 \mu \mathrm{m}$ range, the concentrations of selected pigments were recalculated (Table 6). The number of detected particles within this size range varied between $1.3 \times 10^{5}$ particles $\mathrm{cm}^{-3}(\mathrm{SD}=0.008 \times$ $10^{5}$ particles $\mathrm{cm}^{-3}$ ) for $N$. spumigena to $77.2 \times 10^{5}$ particles $\mathrm{cm}^{-3}\left(\mathrm{SD}=4.9 \times 10^{5}\right.$ particles $\left.\mathrm{cm}^{-3}\right)$ for Nostoc sp. The highest concentrations of all detected pigments in one filament were recorded for $N$. spumigena mainly because of the fact that this species was characterized by the largest filaments among all analyzed cyanobacteria (Fig. 4a). However, it is worth to notice that similarly high values of pigments in one filament were observed for much smaller $P$. cf. galeata (Fig. 4b). The lowest concentrations of all detected pigments were observed for $A$. flos-aquae characterized by rather large sizes (Fig. 4c). Considering these observations, we could not find any dependency between the size of cells/filaments and pigment concentration. However, it is necessary to emphasize here that the results from the Coulter counter should be only treated as an approximation, especially in the case of

filamentous species, because of the measurement technique constraints.

\section{Preservation influence on the spectral shape of phytoplankton absorption}

The comparison of the spectral shape and magnitude of the optical densities obtained for fresh and frozen in liquid nitrogen samples revealed some distinct differences in the case of some strains, as presented in Table 7 and Fig. 5. The lowest differences were observed for Anabaena sp., whereas the highest for $P$. cf. galaeta. For the latter strain, the differences were present within the entire spectrum similarly to the $N$. spumigena spectra. However, for the rest of the analyzed species, the differences around $630 \mathrm{~nm}$ were the highest, i.e., within the spectral region where the absorption by phycobilins are the strongest. However, when the concentrations of some pigments (both carotenoids and phyciobilins) were compared, there were no statistically significant differences among them (Table 8). We suspect that the error in this measurement method can be introduced during the thawing of the filters before the absorption measurement.

\section{Discussion}

The spectral shape and magnitude of the absorption coefficient reflects the phytoplankton pigment composition. Therefore, the absorption or its fourth spectra are often used in order to detect specific pigments and/or identify some phytoplankton species or groups (e.g., Aguirre-Gómez et al. 2001). In the case of phytoplankton containing many different pigments with overlapping absorption bands, the use of derivative analysis in order to determine quantitatively the position and the intensity of the absorption peaks is the easiest and the most convenient way. It is worth to mention that the absorption peaks of particular pigments measured in vivo and in solution are usually shifted, usually by about $10 \mathrm{~nm}$.

Table 8 Results of the non-parametric

Wilcoxon matched pairs test for the concentrations of chosen pigments in fresh and frozen cyanobacteria monoculture samples

\begin{tabular}{llll}
\hline Pigment & $n$ & $Z$ & $p$ \\
\hline Zeaxanthin & 8 & 1.12 & 0.26 \\
Chlorophyll $a$ & 10 & 1.17 & 0.24 \\
Echinenone & 10 & 0.66 & 0.51 \\
$\beta$-carotene & 10 & 0.15 & 0.88 \\
PC & 10 & 1.17 & 0.24 \\
PE & 4 & 1.46 & 0.14 \\
\hline
\end{tabular}

The Wilcoxon test is significant at the 0.01 level

$n$ number of samples, $Z$ test statistic, $p$ confidence level 
However, the difference in the location of absorption peaks can even reach $50 \mathrm{~nm}$ (Bidigare et al. 1990; Smith and Alberte 1994). This effect can be caused by thylakoid membrane degradation as well as disintegration of pigment-protein complexes during pigment extraction (Markwell and Thornber 1982; Smith and Alberte 1994). The magnitude of this shift depends on the type of solvent (e.g., Woźniak and Dera 2007) and the degree of protein complexe degradation (e.g., Markwell and Thornber 1982). For example, in the case of a diatom Phaeodactylum tricornutum, the location of the chlorophyll $a$ maximum in the long wave part of the spectrum varied between 667 and $677 \mathrm{~nm}$ depending on the type of extracted pigment-protein complex (Owens and Wold 1986). Therefore, it seems very important to focus on the in vivo pigment absorption, because it can be very useful in reconstructing phytoplankton absorption spectra based on the HPLC-derived pigment composition.

The absorption of chlorophyll $a$ has been studied for many years. In one of the first works, the absorption peaks were observed at 418, 437, 618, and $673 \mathrm{~nm}$ (Goedheer 1970). However, in more recent papers on various phytoplankton groups, the absorption maxima of this pigment were noted at

a
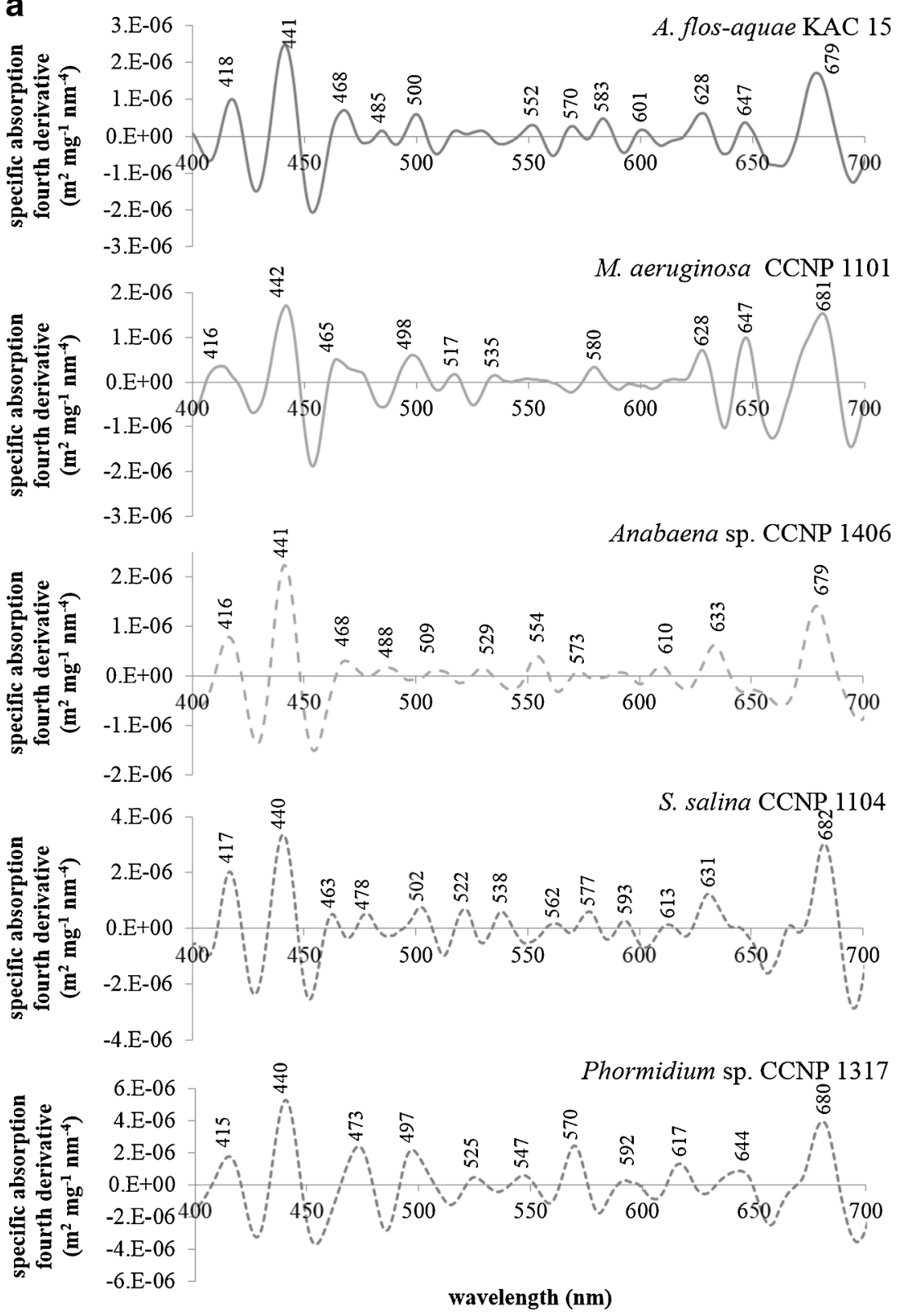

Fig. 6 Chlorophyll-specific absorption fourth derivative spectra of cyanobacteria strains: Aphanizomenon flos-aquae KAC 15, Microcystis aeruginosa CCNP 1101, Anabaena sp. CCNP 1406, Synechocystis salina CCNP 1104, Phormidium sp. CCNP 1317, Nodularia spumigena CCNP

1401, Synechococcus sp. CCNP 1108, Nostoc sp. CCNP 1411, Cyanobacterium sp. CCNP 1105, Pseudanabaena cf. galeata CCNP 1312 

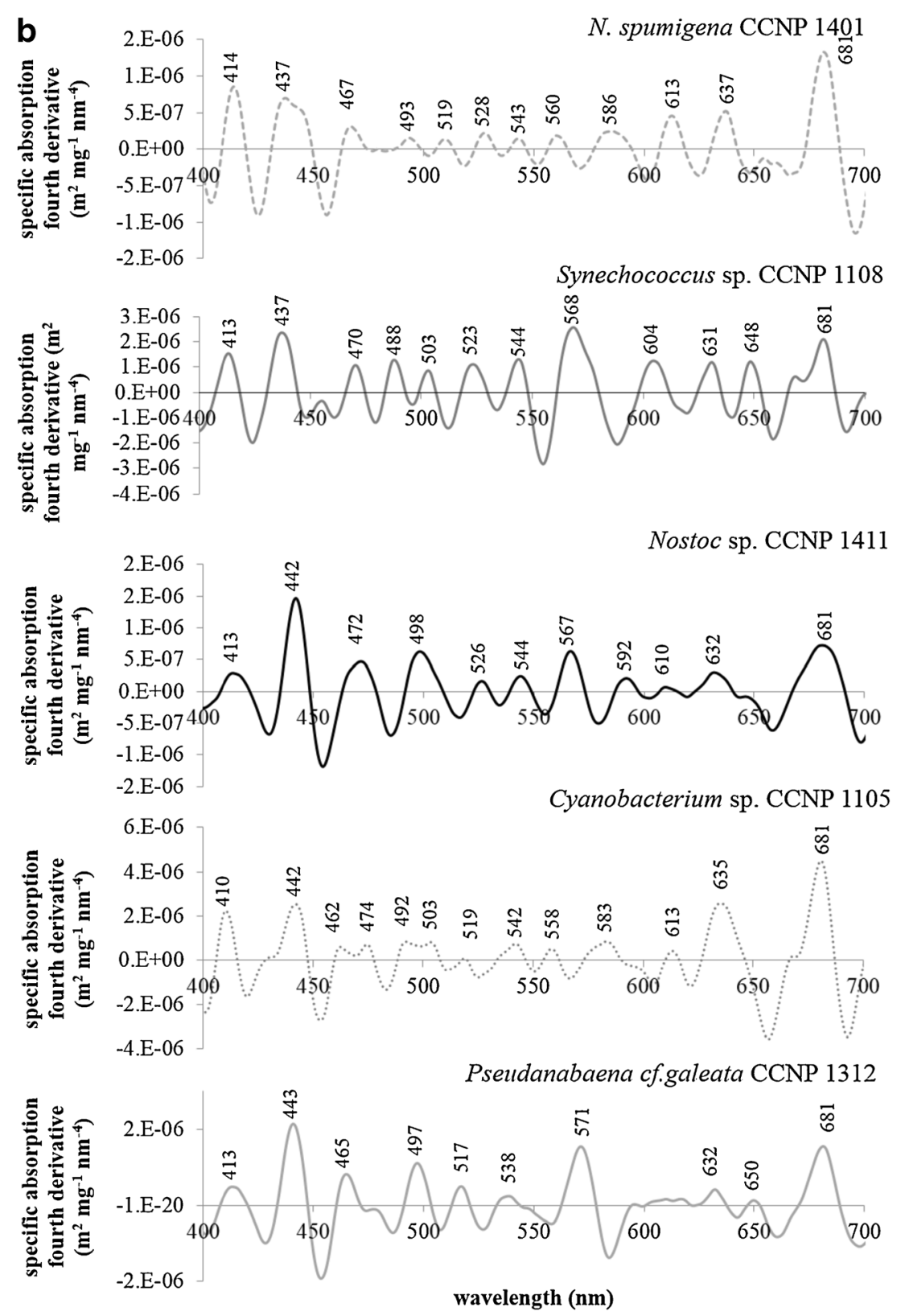

Fig. 6 (continued)

412, 435, 623, and 675 (Hoepffner and Sathyendranath 1991) or 415-425, 440-455, 620, and $675 \mathrm{~nm}$ (Aguirre-Gómez et al. 2001). In this study, we applied the fourth derivative approach to the phytoplankton absorption spectra and we observed distinct absorption peaks of chlorophyll $a$ at 410-418, 437-443, and 679-681 nm (Fig. 6). The absorption maximum observed in previous studies at about $620 \mathrm{~nm}$ can be associated with the peaks between 610 and $632 \mathrm{~nm}$. The main difference observed here is the shift in the long wave in vivo chlorophyll absorption maximum to about $680 \mathrm{~nm}$. However, the differences in the location of this absorption peak among various groups of phytoplankton can be the result of proportion between photosystem I (PS I) and photosystem II (PS II) characterized by different absorptive capabilities (e.g., Hoepffner and Sathyendranath 1991). In all analyzed strains, absorption peaks at 462-474, 492-509, and 517-529 nm were observed. These absorption bands can be clearly associated with carotenoids and xanthophylls like $\beta$-carotene, zeaxanthin, alloxanthin, and aphanizophyll. Such observation was also made by Aguirre-Gómez et al. (2001) who assigned the in vivo absorption maxima around 490 and $536 \mathrm{~nm}$ to a mixture of pigments from the carotenoid and xanthophyll groups. According to Bidigare et al. (1990), the first absorption band is dominated by the absorption of light by $\beta$-carotene. Can be proven by the fact that in the case of Phormidium sp. for which the relative concentration of $\beta$-carotene in relation to 
chlorophyll $a$ was the highest (Fig. 3) and the concentrations of remaining pigments were relatively low (Table 5), the fourth derivative peak at $473 \mathrm{~nm}$ is clearly visible (Fig. 6). The peak between 567 and $571 \mathrm{~nm}$ is clearly caused by the presence of phytoerythrin because it can be noticed only in the case of cyanobacteria for which this pigment was detected (Table 5). This information can be valuable for models for detecting this pigment; however, it does not occur in all cyanobacteria, so it will not be useful in algorithms for cyanobacteria biomass assessment. The last but very distinct absorption peak is located near $630 \mathrm{~nm}$. This absorption band can be clearly associated with the presence of phycyanin (Fig. 6) whose in vivo absorption maximum has been observed at 612-626 nm (e.g., Simis and Kauko 2012).

The fourth derivative analysis of the absorption spectra has been also used in order to approximate the concentration of some pigments (Bidigare et al. 1989; Peréz et al. 2007). In our results, no significant correlation between the value of the fourth derivative and pigment concentrations were observed, even in the case of the chlorophyll $a$ concentration for which such relations were noted in natural samples (Bidigare et al. 1989; Peréz et al. 2007). However, such result can be caused by very low amount of data, and it is necessary to analyze natural samples collected in the areas where cyanobacterial blooms occur.

The use of the fourth derivative analysis can be a valuable tool for determining the location of absorption peaks. However, as it could be observed in the analyzed absorption spectra, the bands of maximum absorption can change depending on the size and shape of organisms. Therefore, the spectra of phytoplankton absorption obtained through the reconstruction based on the HPLC-derived pigment concentration should be treated very carefully. It is very possible that the use of this analysis can be very useful in the case of detecting phytoplankton species in natural samples, especially those characterized by the presence of specific pigments in high concentrations. For example, the derivative analysis has been successfully used in detecting bloom-forming dinoflagellates like Gymnodinium breve or Karenia mikimotoi (Millie et al. 1997; Kirkpatrick et al. 2000; Staehr and Cullen 2003). For the time being, there have been no such trials performed for the Baltic Sea cyanobacteria species. However, such a laboratory approach as we presented here is very useful and should be treated as the first step in the analysis of natural samples which very often lack sharply defined peaks and shoulders which can be clearly seen in laboratory-prepared phytoplankton cultures (e.g., Bidigare et al. 1990).

The main constraint in applying the optical methods for phytoplankton species detection is the lack of knowledge of the variability in absorption and scattering properties under natural conditions. There have been several studies made on the laboratory-grown cyanobacteria cultures (Table 9); however, there is still not much consistency in the obtained results. The changes in the optical properties of phytoplankton cells induced by the light intensity and resulting mainly from changes in pigment composition are a very complicated problem. For some species, the magnitude of the chlorophyllspecific absorption coefficient is almost constant despite highly changing light conditions (e.g., Geider et al. 1985). Whereas for the other species, the observed changes can be very rapid. For example, a 4.5 -fold increase in the $a_{p}{ }^{*}(440)$ value was observed in the case of Synechocystis sp. when the light intensity was changed from 20 to $700 \mu \mathrm{mol}$ photons $\mathrm{m}^{-2} \mathrm{~s}^{-1}$ (Stramski and Morel 1990). It has been observed that the change in pigment composition can be responsible for $14-80 \%$ variability in the magnitude of $a_{p}{ }^{*}(440)$

Table 9 Comparison between the values of chlorophyll-specific absorption coefficients $a_{\mathrm{p}} *(440)$ and $a_{\mathrm{p}} *(675)$ for cyanobacteria monocultures grown under various light conditions (values marked with italics obtained by digitizing appropriate figures in cited publications)

\begin{tabular}{|c|c|c|c|c|}
\hline & \multirow[t]{2}{*}{ Sample type } & \multirow[t]{2}{*}{ Light intensity } & \multicolumn{2}{|c|}{$a_{p}^{*}(\lambda)\left(\mathrm{m}^{2} \mathrm{mg} \mathrm{Chl}_{\mathrm{a}}^{-1}\right)$} \\
\hline & & & $440 \mathrm{~nm}$ & $675 \mathrm{~nm}$ \\
\hline This study & Cyanobacteria monocultures & $7 \mu \mathrm{mol}$ photons $\mathrm{m}^{-2} \mathrm{~s}^{-1}$ & $0.017-0.065$ & $0.014-0.042$ \\
\hline (Wojtasiewicz and Stramski 2010) & Cyanobacteria monocultures & $70 \mu \mathrm{mol}$ photons $\mathrm{m}^{-2} \mathrm{~s}^{-1}$ & $0.032-0.052$ & $0.020-0.031$ \\
\hline (Dupouy et al. 2008) & Trichodesmium spp. & Natural & 0.0278 & 0.0192 \\
\hline \multirow[t]{3}{*}{ (Metsamaa et al. 2006) } & Aphanizomenon flos-aquae & $25 \mu \mathrm{mol}$ photons $\mathrm{m}^{-2} \mathrm{~s}^{-1}$ & 0.032 & 0.017 \\
\hline & Anabaena circinalis & & 0.031 & 0.016 \\
\hline & Nodularia spumigena & & 0.025 & 0.014 \\
\hline (Subramaniam et al. 1999) & Trichodesmium spp. & Natural & 0.04 & 0.01 \\
\hline \multirow[t]{3}{*}{ (Ahn et al. 1992) } & Anacystis marina & $100 \mu \mathrm{mol}$ photons $\mathrm{m}^{-2} \mathrm{~s}^{-1}$ & 0.075 & 0.025 \\
\hline & Synechocystis sp. & & 0.085 & 0.021 \\
\hline & Synechococcus sp. & & 0.12 & 0.045 \\
\hline (Stramski and Morel 1990) & Synechocystis sp. & $20-1450 \mu \mathrm{mol}$ photons $\mathrm{m}^{-2} \mathrm{~s}^{-1}$ & $0.04-0.18$ & - \\
\hline
\end{tabular}


(Babin et al. 1996; Lazzara et al. 1996; Allali et al. 1997; Millán-Núñez et al. 1998; Stuart et al. 1998). Generally, phytoplankton grown under low light conditions is characterized by relatively high concentrations of photosynthetic pigments (Fig. 3, Table 5). It also has been observed that under low light conditions, the relative concentration of phycobillins increases (e.g., Millie et al. 1990; DeNobel et al. 1998; Jodłowska and Latała 2010) affecting the spectral shape of absorption (e.g., Stramski and Morel 1990; Berberoglu and Pilon 2007; Wojtasiewicz and Stramski 2010).

It is also worth noting that a number of remote sensing algorithms has been created to detect harmful algal blooms in various kinds of water reservoirs (Craig et al. 2006; Reinart and Kutser 2006; Hu et al. 2010). However, in inland and coastal environments, the satellite signal is often highly affected by the presence of dissolved organic matter absorbing strongly the light from the short-wave part of the spectrum, which is not the case in the detection methods based on the phytoplankton optical features.

Acknowledgments We would like to thank our colleagues from the Laboratory of Biochemical Ecology of Microorganisms from the University of Gdansk for the help with culturing and working with the cyanobacteria. We are grateful of the anonymous reviewer whose comments and suggestions were helpful to improve the manuscript. The support for this study was provided by the Satellite Monitoring of the Baltic Sea Environment-SatBałtyk project founded by the European Union through European Regional Development Fund contract no. POIG 01.01.02-22-011/09.

Open Access This article is distributed under the terms of the Creative Commons Attribution 4.0 International License (http:// creativecommons.org/licenses/by/4.0/), which permits unrestricted use, distribution, and reproduction in any medium, provided you give appropriate credit to the original author(s) and the source, provide a link to the Creative Commons license, and indicate if changes were made.

\section{References}

Aguirre-Gómez R, Weeks AR, Boxall SR (2001) The identification of phytoplankton pigments from absorption spectra. Int J Remote Sens 22:315-338

Ahn Y-H, Bricaud A, Morel A (1992) Light backscattering efficiency and related properties of some phytoplankters. Deep-Sea Res 39:18351855

Allali K, Bricaud A, Claustre H (1997) Spatial variations in the chlorophyll-specific absorption coefficients of phytoplankton and photosynthetically active pigments in the equatorial Pacific. J Geophys Res 102:12413-12423

Babin M, Morel A, Claustre H, Bricaud A, Kolber Z, Falkowski PG (1996) Nitrogen- and irradiance-dependent variations of the maximum quantum yield of carbon fixation in eutrophic, mesotrophic and oligotrophic marine systems. Deep-Sea Res I 43:1241-1272

Barlow RG, Mantoura RFC, Gough MA, Fileman TW (1993) Pigment signatures of the phytoplankton composition in the north-eastern Atlantic during the 1990 spring bloom. Deep-Sea Res II 40:459-477

Berberoglu H, Pilon L (2007) Experimental measurements of the radiation characteristics of Anabaena variabilis ATCC 2941-U and
Rhodobacter sphaeroides ATCC 49419. Int J Hydrog Energy 32: $4727-4785$

Bidigare RR, Morrow JH, Kiefer DA (1989) Derivative analysis of spectral absorption by photosynthetic pigments in the western Sargasso Sea. J Mar Res 47:323-341

Bidigare RR, Ondrusek ME, Morrow JH, Kiefer DA (1990) In vivo absorption properties of algal pigments. Proc. SPIE 1302. Ocean Optics X 290:290-302

Bricaud A, Babin M, Morel A, Claustre H (1995) Variability in the chlorophyll-specific absorption coefficients of natural phytoplankton: Analysis and parameterization. J Geophys Res 100:1332113332

Chami M, Santer R, Dilligeard E (2001) Radiative transfer model for the computation of radiance and polarization in an ocean-atmosphere system: polarization properties of suspended matter for remote sensing. Appl Opt 40:2398-2416

Craig SE, Lohrenz SE, Lee Z, Mahoney KL, Kirkpatrick GJ, Schofield OM (2006) Use of hyperspectral remote sensing reflectance for detection and assessment of the harmful alga, Karenia brevis. Appl Opt 45:5414-5425

DeNobel WT, Matthijs HCP, von Elert E, Mur LR (1998) Comparison of the light-limited growth of the nitrogen-fixing cyanobacteria Anabaena and Aphanizomenon. New Phytol 138:579-587

Dupouy C, Neveux J, Dirberg G, Röttgers R, Tenório MMB, Ouillon S (2008) Bio-optical properties of marine cyanobacteria Trichodesmium spp. J Appl Remote Sens 2:023503

Ficek D, Kaczmarek S, Stoń-Egiert J, Woźniak B, Majchrowski R, Dera J (2004) Spectra of light absorption by phytoplankton pigments in the Baltic: conclusions to be drawn from a Gaussian analysis of empirical data. Oceanologia 46:533-555

Geider RJ, Osborne BA, Raven JA (1985) Light dependence of growth and photosynthesis in Phaeodactylum tricornutum (Bacillariophyceae). J Phycol 21:609-619

Goedheer JC (1970) On the pigment system of brown algae. Photosynthetica 4:97-106

Goodwin TW (1957) The nature and distribution of carotenoids in some blue-green algae. J Gen Microbiol 17:467-478

Grossman AR, Schaefer MR, Chiang GG, Collier JL (1993) The phycobilisome, a light-harvesting complex responsive to environmental conditions. Microbiol Rev 57:725-749

Hoepffner N, Sathyendranath S (1991) Effect of pigment composition on absorption properties of phytoplankton. Mar Ecol Prog Ser 73:1123

Hu C, Cannizzaro J, Carter KL, Muller-Karger FE, Hardy R (2010) Remote detection of Trichodesmium blooms in optically complex coastal waters: Examples with MODIS full-spectral data. Remote Sens Environ 114:2048-2058

Jodłowska S, Latała A (2010) Photoacclimation strategies in the toxic cyanobacterium Nodularia spumigena (Nostocales, Cyanobacteria). Phycologia 49:203-211

Kahru M, Horstmann U, Rud O (1994) Satellite detection of increased cyanobacteria blooms in the Baltic Sea: natural fluctuation or ecosystem change. Ambio 23:469-472

Kirkpatrick GJ, Millie DF, Moline MA, Schofield O (2000) Optical discrimination of a phytoplankton species in natural mixed populations. Limnol Oceanogr 45:467-471

Kishino M, Takahashi N, Okami N, Ichimura S (1985) Estimation of the spectral absorption coefficients of phytoplankton in the sea. Bull Mar Sci 37:634-642

Kobos J, Mazur-Marzec H, Dittmer B, Witek B, Pliński M (2005) Toxic cyanobacterial blooms in the Kociewskie Lakes (Northern Poland). Oceanol Stud 34:77-84

Kobos J, Błaszczyk A, Hohlfeld N, Toruńska-Sitarz A, Krakowiak A, Hebel A, Sutryk K, Grabowska M, Toporowska M, Kokociński M, Messyasz B, Rybak A, Napiórkowska-Krzebietke A, Nawrocka L, Pełechata A, Budzyńska A, Zagajewski P, Mazur- 
Marzec H (2013) Cyanobacteria and cyanotoxins in Polish freshwater bodies. Oceanol Hydrobiol Stud 42:358-378

Kotai J (1972) Instructions for preparation of mdified nutrient solution Z8 for algae. Norwegian Institute for Water Research B-11769: Blindern, Oslo, Norway, p 5

Lazzara L, Bricaud A, Claustre H (1996) Spectral absorption and fluorescence excitation properties of phytoplanktonic populations at a mesotrophic and an oligotrophic site in the tropical North Atlantic (EUMELI program). Deep-Sea Res I 43:1215-1240

Lokuhewage AUM, Fujino T (2011) Two cyanobacterial strains can be distinguished from each other and other eukaryotic algae by spectral absorption method. Water Sci Technol 63:1203-1210

Lokuhewage AUM, Naiki Y, Toyooka S (2005) Quantitative estimation of phytoplankton species in freshwater by two step linear regression analysis using spectral absorption method. Opt Rev 12:420-426

MacColl R (1998) Cyanobacterial phycobilisomes. J Struct Biol 124: 311-334

Mackey MD, Mackey DJ, Higgins HW, Wright SW (1996) CHEMTAX - a program for estimating class abundances from chemical markers: application to HPLC measurements of phytoplankton. Mar Ecol Prog Ser 144:265-283

Mantoura RFC, Llewellyn CA (1983) The rapid determination of algal chlorophyll and carotenoid pigments and their breakdown products in natural waters by reverse-phase high-performance liquid chromatography. Anal Chim Acta 151:297-314

Markwell JP, Thornber JP (1982) Treatment of the tylakoid membrane with surfactants: assessment of the effectiveness using the chlorophyll $a$ absorption spectrum. Plant Physiol 70:633-636

Mazur-Marzec H, Sutryk K, Kobos J, Hebel A, Hohlfeld N, Błaszczyk A, Toruńska A, Kaczkowska MJ, Łysiak-Pastuszak E, Kraśniewski W, Jesser I (2013) Occurrence of cyanobacteria and cyanotoxin in the Southern Baltic Proper. Filamentous cyanobacteria versus singlecelled picocyanobacteria. Hydrobiologia 701:235-252

Mazur-Marzec H, Błaszczyk A, Felczykowska A, Hohlfeld N, Kobos J, Toruńska-Sitarz A, Devi P, Montalvao S, D’Souza L, Tammela P, Mikosik A, Bloch S, Nejman-Faleńczyk B, Węgrzyn G (2015) Baltic cyanobacteria - a source of biologically active compounds. Eur J Phycol 50:343-360

Metsamaa L, Kutser T, Strömbeck N (2006) Recognising cyanobacterial blooms based on their optical signatures: a modeling study. Boreal Environ Res 11:493-506

Millán-Núñez E, Lara-Lara JR, Cleveland JS (1998) Variations in specific absorption coefficients and total phytoplankton in the Gulf of California. CalCOFl Rep 39:159-168

Millie DF, Ingram DA, Dionigi CP (1990) Pigment and photosynthetic responses of Oscillatoria agardhii (Cyanophyta) to photon flux density and spectral quality. J Phycol 26:660-666

Millie DF, Schofield OM, Kirkpatrick GJ, Johnsen G, Tester PA, Vinyard BT (1997) Detection of harmful algal blooms using pheopigments and absorption signatures: a case study of the Florida red tide, Gymnodinium breve. Limnol Oceanogr 42:1240-1251

Millie DF, Schofield OM, Kirkpatrick GJ, Johnsen G, Evens TJ (2002) Using absorbance and fluorescence spectra to discriminate microalgae. Eur J Phycol 37:313-322

Moberg L, Karlberg B, Sørensen K, Källqvist T (2002) Assessment of phytoplankton class abundance using absorption spectra and chemometrics. Talanta 56:153-160

Mobley CD (1994) Light and water: radiative transfer in natural waters. Academic Press, San Diego

Mobley CD, Gentili B, Gordon HR, Jin Z, Kattawar GW, Morel A, Reinersman P, Stamnes K, Stavn RH (1993) Comparison of numerical models for computing underwater light fields. Appl Opt 32: 7484-7504

Owens TG, Wold ER (1986) Light-harvesting in the diatom Phaeodactylum tricornutum I. Isolation and characterization of pigment-protein complexes. Plant Physiol 80:732-738
Parsons TR, Maita Y, Lalli CA (1984) A manual of chemical and biological methods for seawater analysis. Pergamon Press, Oxford

Peréz G, Queimalinos C, Balseiro E, Modenutti B (2007) Phytoplankton absorption spectra along the water column in deep North Patagonian Andean lakes (Argentina). Limnologica 37:3-16

Pliński M, Musiał A, Ostrowski B (1998) Blue-green algae blooms in the Gulf of Gdańsk and surrounding area. Oceanol Stud 27:179-183

Pliński M, Mazur-Marzec H, Jóźwiak T, Kobos J (2007) The potential causes of cyanobacterial blooms in Baltic Sea estuaries. Oceanol Stud 36:125-137

Reinart A, Kutser T (2006) Comparison of different satellite sensors in detecting cyanobacterial bloom events in the Baltic Sea. Remote Sens Environ 102:74-85

Röttgers R, Gehnke S (2012) Measurement of light absorption by aquatic particles: improvement of the quantitative filter technique by use of an integrating sphere approach. Appl Opt 51:1336-1351

Röttgers R, Häse C, Doerffer R (2007) Determination of the particulate absorption of microalgae using a point-source integrating cavity absorption meter: verification with a photometric technique, improvements for pigment bleaching, and correction for chlorophyll fluorescence. Limnol Oceanogr Methods 5:1-12

Roy S, Llewellyn CA, Egeland ES, Johnsen G (2011) Phytoplankton pigments: characterization, chemotaxonomy, and applications in oceanography. Cambridge University Press, Cambridge

Schagerl M, Müller B (2006) Acclimation of chlorophyll a and carotenoid levels to different irradiances in four freshwater cyanobacteria. J Plant Physiol 163:709-716

Sellner K (1997) Physiology, ecology, and toxic properties of marine cyanobacteria blooms. Limnol Oceanogr 42:1089-1104

Simis SGH, Kauko HM (2012) In vivo mass-specific absorption spectra of phycobilipigments through selective bleaching. Limnol Oceanogr Methods 10:214-226

Smith CM, Alberte RS (1994) Characterization of in vivo absorption features of chlorophyte, phaeophyte, and rhodophyte algal species. Mar Biol 118:511-521

Sobiechowska-Sasim M, Stoń-Egiert J, Kosakowska A (2014) Quantitative analysis of extracted phycobilin pigments in cyanobacteria - an assessment of spectrophotometric and spectrofluorometric methods. J Appl Phycol 26:2065-2074

Sosik HM (1996) Bio-optical modeling of primary production: consequences of variability in quan-tum yield and specific absorption. Mar Ecol Prog Ser 143:225-238

Staehr PA, Cullen JJ (2003) Detection of Karenia mikimotoi by spectral absorption signatures. J Plankton Res 25:1237-1249

Stal LJ, Albertano P, Bergman B, von Bröckel K, Gallon RJ, Haes PK, Sivonen K, Walsby AE (2003) BASIC: Baltic Sea cyanobacteria. An investigation of the structure and dynamics of water blooms of cyanobacteria in the Baltic Sea-responses to a changing environment. Cont Shelf Res 23:1695-1714

Steward DE, Farmer FH (1984) Extraction, identification, and quantitation of phycobiliprotein pigments in phototrophic plankton. Limnol Oceanogr 29:2065-2074

Stoń J, Kosakowska A (2002) Phytoplankton pigments designation - an application of RP-HPLC in qualitative and quantitative analysis. J Appl Phycol 14:205-210

Stoń-Egiert J, Kosakowska A (2005) RP-HPLC determination of phytoplankton pigments - comparison of calibration results for two columns. Mar Biol 147:251-260

Stramska M, Stramski D, Hapter R, Kaczmarek S, Stoń J (2003) Biooptical relationships and ocean color algorithms for the north polar region of the Atlantic. J Geophys Res. doi:10.1029/2001JC001195

Stramski D, Morel A (1990) Optical properties of photosynthetic picoplankton in different physiological states as affected by growth irradiance. Deep-Sea Res 37:245-266

Stramski D, Piskozub J (2003) Estimation of scattering error in spectrophotometric measurements of light absorption by aquatic particles 
form three-dimensional radiative transfer simulations. Appl Opt 42: 3634-3646

Stramski D, Sciandra A, Claustre H (2002) Effects of temperature, nitrogen, and light limitation on the optical properties of the marine diatom Thalassiosira pseudonana. Limnol Oceanogr 47:392-403

Stuart V, Sathyendranath S, Platt T, Maass H, Irwin BD (1998) Pigments and species composition of natural phytoplankton populations: effect on the absorption spectra. J Plankton Res 20:187-217

Subramaniam A, Carpenter EJ, Karentz D, Falkowski PG (1999) Biooptical properties of marine diazotrophic cyanobacteria Trichodesmium spp. I. Absorption and photosynthetic absorption spectra. Limnol Oceanogr 44:608-617
Tassan S, Ferrari GM (1995) An alternative approach to absorption measurements of aquatic particles retained on filters. Limnol Oceanogr 40:1358-1368

van de Hulst HC (1957) Light scattering by small particles. John Wiley, New York

Wojtasiewicz B, Stramski D (2010) Chlorophyll-specific absorption and scattering coefficients of selected cyanobacteria. Anchorage, Alaska

Woźniak SB (2014) Simple statistical formulas for estimating biogeochemical properties of suspended particulate matter in the southern Baltic Sea potentially useful for optical remote sensing applications. Oceanologia 56:7-39

Woźniak B, Dera J (2007) Light absorption in sea water. Springer, New York 